\title{
Analisis Kemampuan Bercerita Siswa dengan Metode Kerja Kelompok Kecil Siswa Kelas III Tema 6 Energi dan Perubahannya di SD Negeri 02 Penjor Kecamatan Pagerwojo Kabupaten Tulungagung Tahun Ajaran 2018/2019
}

\author{
Azaz Uddin ${ }^{1^{*}}$, dan Nourma Oktaviarini ${ }^{2}$ \\ STKIP PGRI TULUNGAGUNG \\ E-mail: azazu398@gmail.com nourma@stkippgritulungagung.ac.id
}

\begin{abstract}
Abstrak
Analisis kemampuan bercerita siswa dengan metode kerja kelompok kecil siswa kelas iii tema 6 energi dan perubahannya di sd negeri 02 penjor kecamatan pagerwojo kabupaten tulungagung tahun ajaran 2018/2019 Penelitian ini bertujuan untuk mendeskripsikan dan menganalisis kemampuan bercerita siswa kelas III SD Negeri 02 Penjor. Penelitian ini menggunakan metode kualitatif. Subjek dalam penelitian ini adalah siswa kelas III yang berjumlah 17 siswa. teknik pengumpulan data dalam penelitian ini yaitu wawancara dan obsevasi. Hasil penelitian menunjukan hasil perhitungan keseluruhan kemampuan bercerita siswa kelas III di SD Negeri 02

Penjor menunjukkan angka 501 dengan prosentase sebesar $84 \%$ dalam kategori "sangat baik". Berdasarkan hasil bercerita siswa dengan kategori "sangat baik" maka pembelajaran keterampilan bercerita dengan menggunakan model pembelajaran kerja kelompok kecil ini dapat memotivasi siswa untuk belajar lebih baik dalam menggunakan dan mengucapkan kalimat dengan bahasa Indonesia dan dapat meningkatkan keterampilan bercerita siswa
\end{abstract}

Kata Kunci :Bercerita, Kemampuan Bercerita, Metode Kerja Kelompok Kecil

\section{PENDAHULUAN}

Pembelajaran bahasa Indonesia termasuk di dalamnya adalah materi bercerita. Bercerita di kelas III sekolah dasar diajarkan melalui metode pembelajaran tematik terpadu yang merupakan implementasi dari Kurikulum 2013. Ketrampilan bercerita adalah sesuatu yang mengisahkan tentang perbuatan atau suatu kejadian dan disampaikan secara lisan dengan tujuan membagikan pengalaman dan pengetahuan kepada orang lain (Bachir, 2005, hal. 10), belajar bercerita menjadi sangat penting bagi anak didik sekolah dasar karenanya merupakan bagian dari proses belajar komunikasi, dalam tahap pendidikan dasar bercerita juga bisa diartikan sebagai upaya belajar berbahasa atau berbicara (speaking) secara baik dan benar. Berdasarkan observasi awal pada tanggal 28 Januari 2019 di kelas 3 SD Negeri 02 Penjor Kecamatan Pagerwojo Kabupaten Tulungagung diketahui bahwa kemampuan bercerita siswa kelas III masih ada beberapa siswa melakukan kesalahan atau hambatan saat bercerita. Solusi yang dipilih untuk mengatasi masalah rendahnya ketrampilan berbicara siswa salah satunya adalah menggunakan model pembelajaran kerja kelompok kecil, Kerja kelompok kecil adalah suatu metode mengajar dengan membagi siswa menjadi beberapa kelompok dan mereka bekerja sama dalam memecah menjadi beberapa kelompok dan mereka bekerja sama dalam memecahkan masalah atau melaksanakan tugas tertentu dan berusahamencapai tujuan pengajaran yang telah ditentukan oleh guru. Sesuai dengan pendapat Martin (dalam roestiyah, 2008, hal. 15).

Melalui metode kerja kelompok kecil ini guru membagi siswa ke dalam beberapa kelompok 
apa yang mereka pahami dari gambar tersebut didepan kelas. Menerapkan model pembelajaran kerja kelompok kecil tentunya akan membuat siswa lebih mudah untuk memahami pelajaran karena menggunakan bahasa atau kalimat mereka sendiri. Dengan diterapkannya metode kerja kelompok kecil ini diharapkan oleh guru kelas III SD 02 Penjor tujuan pembelajaran akan tercapai dan proses pembelajaran yang dialami oleh siswa akan lebih bermakna serta pelajaran ketrampilan bercerita menjadi pelajaran yang menyenangkan dan tidak membosankan, untuk itu dalam proses pembelajaran ketrampilan bercerita harus kreatif dan menyenangkan dengan menggunakan metode kerja kelompok kecil. Dari latar belakang di atas peneliti tertarik untuk melaksanakan penelitian dengan judul analisis kemampuan bercerita siswa dengan metode kerja kelompok kecil siswa kelas III tema 6 energi dan perubahannya di SD Negeri 02 Penjor Kecamatan Pagerwojo Kabupaten Tulungagung tahun ajaran 2018/2019.

\section{METODE/EKSPERIMEN}

Penelitian ini menggunakan desain penelitian kualitatif. Moleong (2012, hal. 4) menjelaskan tentang penelitian kualitatif sebagai Penelitian yang digunakan untuk untuk memahami fenomena yang dialami oleh subjek penelitian misalnya perilaku, persepsi, motivasi, tindakan dan lain-lain, yang secara utuh dengan cara dideskripsikan dalam bentuk kata-kata dan bahasa pada konteks khusus yang alami dengan memanfaatkan metode alamiah. Jenis penelitian ini adalah deskriptif kualitatif. Nawawi dan Martini (1996, hal. 73) mendefinisikan maksud dari penelitian deskriptif kualitatif sebagai

"penelitian yang menggambarkan atau melukiskan objek penelitian berdasarkan fakta-fakta yang tampak atau sebagaimana adanya".

Subjek penelitian ini adalah peserta didik kelas III SD Negeri 02 Penjor, Kecamatan Pagerwojo, Kabupaten Tulungagung tahun ajaran 2018/2019 Kelas tersebut memiliki jumlah peserta didik sebanyak 17 siswa, terdiri dari 11 siswa laki-laki dan 6 siswa perempuan. Observasi awal dilaksanakan pada tanggal 28 januari 2019. . Kisi-kisi lembar observasi siswa dan guru dapat dilihat pada tabel sebagai berikut.

Tabel 1

Kisi- Kisi Pedoman Observasi Siswa Dalam Keterampilan Bercerita

\begin{tabular}{|c|c|c|c|}
\hline Aspek o & & Indikator & $\begin{array}{r}\text { Butir } \\
\text { Pernyataan }\end{array}$ \\
\hline \multirow{6}{*}{$\begin{array}{l}\text { Keterampilan } \\
\text { aspek Kebahasaan }\end{array}$} & berbicara dalam & Ketepatan isi cerita & 1 \\
\hline & & $\begin{array}{ll}\text { Ketepatan penunjukan detail } \\
\text { cerita }\end{array}$ & 2 \\
\hline & & Ketepatan logika cerita & 3 \\
\hline & & $\begin{array}{l}\text { Ketepatan makna keseluruhan } \\
\text { cerita }\end{array}$ & 4 \\
\hline & & Ketepatan kata & 5 \\
\hline & & Ketepatan kalimat & 6 \\
\hline $\begin{array}{l}\text { Keterampilan } \\
\text { bercerita aspek } \\
\text { Nonkebahasaan }\end{array}$ & dalam & Kelancaran & 7 \\
\hline
\end{tabular}

Tabel 2

Kisi-kisi Pedoman Observasi Guru Dalam Pembelajaran

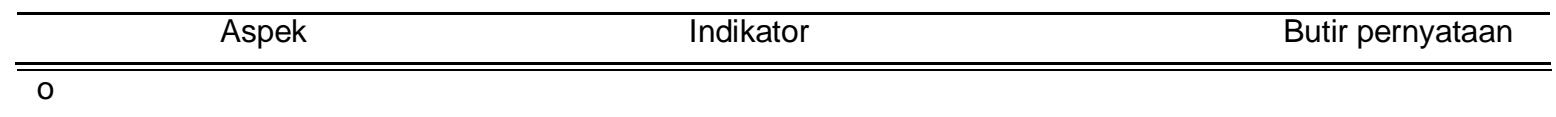




\begin{tabular}{lcc}
\hline \multirow{2}{*}{ Awal pembelajaran } & \multicolumn{1}{c}{ Membuka proses pembelajaran } & $1,2,3$ \\
\cline { 3 - 3 }. & Apresepsi & $4,5,6,7$ \\
\hline Inti pembelajaran & Penerapan model pembelajaran & $8,9,10,11,12$, \\
& kerja kelompok kecil & 13,14 \\
\hline Akhir pembelajaran & Evaluasi proses pembelajaran & $15,16,17$ \\
\cline { 2 - 3 } & & $18,19,20$ \\
\hline
\end{tabular}

Untuk mempermudah pemahaman peneliti atau pembaca dalam menentukan skor penilaian keterampilan berbicara siswa dan dipaparkan lembar penilaian yang dikembangkan peneliti tersaji pada halaman lampiran. Pada penelitian ini dalam penilaian lembar observasi menggunakan skala likert yang digunakan skala likert untuk pernyataan positif.

Tabel 3

Skala Likert Kisi-Kisi Penilaian Lembar Observasi

\begin{tabular}{llllll}
\hline Item pernyataan B & \multicolumn{6}{l}{ Bobot Skor } & & \\
\cline { 2 - 6 } & S & B & CB & KB & TB \\
\hline Positif & 5 & 4 & 3 & 2 & 1 \\
\hline Negatif & 1 & 2 & 3 & 4 & 5
\end{tabular}

(Sukardi 2013, hal. 147) Keterangan:

SB = Sangat baik

$\mathrm{B} \quad=$ Baik

$\mathrm{CB} \quad=$ Cukup baik

$\mathrm{KB} \quad=$ Kurang baik

TB = Tidak baik

Perhitungan capaian ketrampilan berbicara masing-masing siswa pada pembelajaran dilakukan menggunakan rumus sebagai berikut (Sukardi 2013, hal. 67)

Capaian $=\frac{\text { jumlah skor yang diperoleh }}{\text { skor maksimal }} \times 100$

Data yang digunakan adalah data primer dan sekunder. Data ini berupa data tertulis dari hasil pekerjaan siswa dalam menyelesaikan operasi hitung pembagian dan data dalam bentuk kata-kata dan perilaku yang diperoleh dari wawancara dan observasi.

\section{HASIL DAN PEMBAHASAN}

Pelaksanaan proses pembelajaran kemampuan bercerita dengan menggunakan model pembelajaran kerja kelompok kecil siswa terlihat aktif berlatih secara berkelompok, dalam proses pembelajaran guru memberikan sebuah teks bacaan cerita untuk dibagikan masing-masing kelompok, lalu guru meminta siswa untuk mempelajari bagian mereka masing-masing sambil membuat catatan yang menjadi kata kunci dari materi yang menjadi bagian mereka. Setelah itu mereka saling bertukar informasi. Kemudian siswa secara berkelompok/berpasangan menceritakan kembali teks bacaan yang telah diperoleh siswa. Kegiatan diakhiri dengan diskusi mengenai topik dalam bahan pelajaran hari itu.

Berikut ini penjelasan dari proses keterlaksanaan pembelajaran keterampilan berbicara dengan menggunakan model pembelajaran kerja kelompok kecil siswa kelas III SD Negeri 02 Penjor:

Kegiatan Awal

Guru memberikan salam kepada siswa, lalu guru meminta siswa untuk memimpin doa sebelum mengawali pembelajaran, selanjutnya guru melakukan presensi siapa yang tidak masuk pada hari itu. 
Untuk lebih semangat guru mengajak siswa menyanyikan Lagu "Indonesia Raya" dan menanamkan semangat kebangsaan kepada siswa. Guru menyampaikan apresepsi kepada siswa mengenai tujuan pembelajaran yang akan dipelajari dan mengaitkan materi dengan kehidupan seharihari yaitu mengidentifikasi tentang berbagai macam energi dan perubahannya pada gambar yang ada di buku. Guru mengaitkan kegiatan ini dengan judul tema "Energi dan Perubahanya".

Kegiatan Inti

Kegiatan selanjutnya guru memberikan beberapa pertanyaan kepada siswa mengenai tujuan pembelajaran yang sedang dipelajari untuk memancing pengetahuan siswa yaitu

"1. Energi-energi apa saja yang ditunjukkan gambar gambar tersebut? 2. Apakah energi berguna bagi manusia? Mengapa? 3. Keuntungan apa yang diperoleh manusia jika memanfaatkan energi?". Siswa merespon pertanyaan dari guru secara bersama-sama, sebagian siswa menjawab pertanyaan dengan tepat dari guru. Kemudian guru menginformasikan bahwa pembelajaran pada hari ini adalah tema 6 Energi dan Perubahannya.

Setelah guru memberikan gambaran mengenai materi yang dibahas pada materi tersebut. Kemudian guru membagi siswa menjadi kelompok kecil masing-masing kelompok terdiri dari 4-5 orang siswa lalu. Langkah selanjutnya adalah guru memberikan teks bacaan kepada masing-masing siswa, dan meminta siswa untuk mempelajari bagian mereka sambil membuat catatan yang menjadi kata kunci dari materi yang menjadi bagian mereka. Guru meminta siswa untuk memahami/menghafal bagian mereka pada teks bacaan yang sudah dibagi. Setelah itu mereka saling bertukar informasi. Kemudian siswa secara bergantian satu persatu menceritakan kembali teks bacaan yang telah diperoleh siswa di depan kelas.

Kegiatan Akhir

Kegiatan akhir pembelajaran guru bertanya kepada beberapa siswa tentang kesimpulan materi yang dipelajari. Guru memberikan kesempatan untuk siswa bertanya mengenai materi yang dipelajari hari ini. Guru memberikan beberapa soal mengenai materi yang yang telah dipelajari. Guru dan siswa menyimpulkan kegiatan pelajaran yang telah dipelajari. Guru meminta siswa untuk mencatat hal-hal penting pada pembelajaran hari ini. Selanjutnya guru memberi motivasi kepada siswa untuk terus belajar. Kegiatan diakhiri dengan doa pada pelajaran hari itu.

Penerapan pembelajaran keterampilan bercerita dengan menggunakan model pembelajaran kerja kelompok kecil sangat bermanfaat bagi siswa. Siswa tidak mudah bosan dengan pembelajaran berlangsung karena adanya perubahan model pembelajaran disetiap pertemuannya. Dengan model pembelajaran ini, siswa menjadi bertanggung jawab terhadap dirinya sendiri dan kelompoknya. Siswa juga lebih memahami materi karena mereka mengingatnya dengan menggunakan kalimat mererka sendiri. Siswa mampu mengembangkan kalimat dengan kata-kata mereka sendiri. Selain itu, mereka juga bisa lebih bertanggung jawab dalam melakukan diskusi. Mereka dapat menceritakan bacaan dengan dengan kosakata/diksi yang baik dan benar. Apabila diminta untuk bercerita di depan kelas, mereka juga tidak malu-malu lagi. Rasa percaya diri mereka menjadi meningkat. Selain itu, mereka juga dapat berdiskusi dan bekerja sama dengan temannya dengan baik.

Observasi keterampilan berbicara siswa terdiri dari atas 7 aspek indikator yaitu ketepatan isi cerita, ketepatan penunjukan cerita, ketepatan logika bercerita, ketepatan keseluruhan makna cerita, ketepatan pemilihan kata, ketepatan kalimat, kelancaran. Observasi ini dilakukan kepada siswa SD Negeri 02 Penjor saat jam berlangsung. Adapun hasil observasi keterampilan bercerita siswa menggunakan model kerja kelompok kecil dijabarkan dalam tabel dibawah ini.

Tabel 4 Hasil Observasi Keterampilan Berbicara Siswa

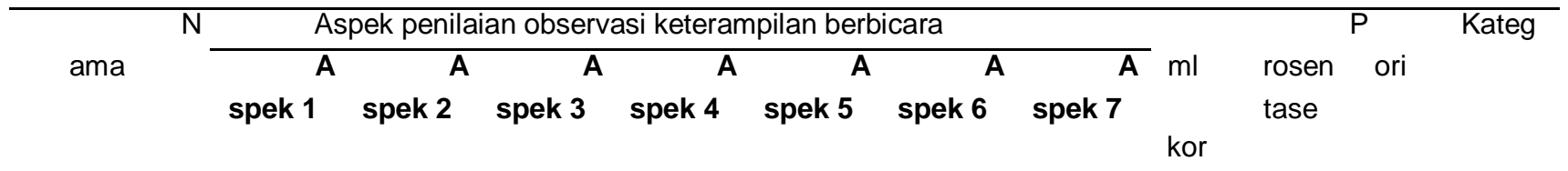




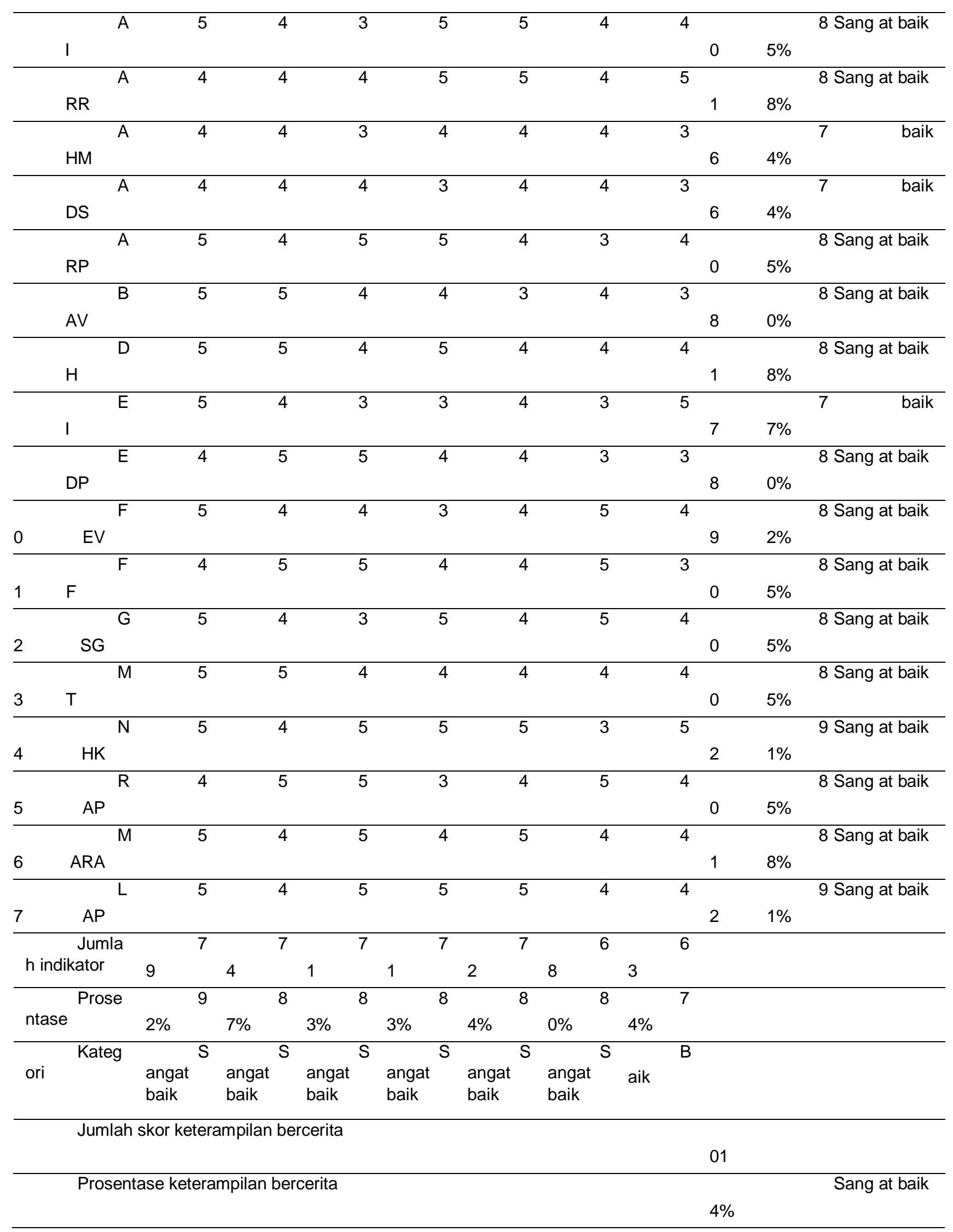

Berdasarkan tabel 4 lembar penilaian kemampuan bercerita siswa dengan menggunakan model pembelajaran kerja kelompok kecil dapat diketahui bahwa Pada aspek 1 (Ketepatan isi cerita) diperoleh 
hasil skor menunjukkan angka 79 dengan prosentase $92 \%$ dari 17 siswa yang tergolong dalam kategori baik. Pada aspek 2 (Ketepatan penunjukan cerita) diperoleh hasil skor menunjukkan angka 74 dengan prosentase $87 \%$ dari 17 siswa yang tergolong dalam kategori baik. Pada aspek 3 (ketepatan logika bercerita) diperoleh hasil skor menunjukkan angka 71 dengan prosentase $83 \%$ dari 17 siswa yang tergolong dalam kategori baik. Pada aspek 4 (ketepatan kesuluruhan makna cerita) diperoleh hasil skor menunjukkan angka 71 dengan prosentase $83 \%$ dari 17 siswa yang tergolong dalam kategori baik. Pada aspek 5 (ketepatan pemiihan kata) diperoleh hasil skor menunjukkan angka 72 dengan prosentase $84 \%$ dari 17 siswa yang tergolong dalam kategori sangat baik. Pada aspek 6 (ketepatan kalimat) diperoleh hasil skor menunjukkan angka 68 dengan prosentase $80 \%$ dari 17 siswa yang tergolong dalam kategori sangat baik. Pada aspek 7 (kelancaran) diperoleh hasil skor menunjukkan angka 63 dengan prosentase $74 \%$ dari 17 siswa yang tergolong dalam kategori baik

Berdasarkan analisis hasil penelitian dan pembahasan menunjukkan bahwa hasil observasi pelaksanaan pembelajaran kemampuan bercerita menggunakan model pembelajaran kerja kelompok kecil pada tema 6 energi dan perubahannya siswa kelas III SD Negeri 02 Penjor yang diterapkan guru sudah sesuai dengan prosedur atau langkah-langkah dalam penerapan model pembelajaran kerja kelompok kecil memperoleh hasil prosentase sebesar $84 \%$ dan termasuk dalam kategori "sangat baik". Pelaksanaan kegiatan pembelajaran kelompok kecil hari itu sejalan dengan pendapat Abu Ahmadi (1997, hal. 91)

Data hasil penelitan kemampuan bercerita siswa dengan menggunakan model pembelajaran kerja kelompok kecil dapat diketahui bahwa Pada aspek 1 (Ketepatan isi cerita) diperoleh hasil skor menunjukkanangka 79 dengan prosentase $92 \%$ dari 17 siswa yang tergolong dalam kategori baik. Pada aspek 2 (Ketepatan penunjukan cerita) diperoleh hasil skor menunjukkan angka 74 dengan prosentase 87\% dari 17 siswa yang tergolong dalam kategori baik. Pada aspek 3 (ketepatan logika bercerita) diperoleh hasil skor menunjukkan angka 71 dengan prosentase $83 \%$ dari 17 siswa yang tergolong dalam kategori baik. Pada aspek 4 (ketepatan kesuluruhan makna cerita) diperoleh hasil skor menunjukkan angka 71 dengan prosentase $83 \%$ dari 17 siswa yang tergolong dalam kategori baik. Pada aspek 5 (ketepatan pemiihan kata) diperoleh hasil skor menunjukkan angka 72 dengan prosentase $84 \%$ dari 17 siswa yang tergolong dalam kategori sangat baik. Pada aspek 6 (ketepatan kalimat) diperoleh hasil skor menunjukkan angka 68 dengan prosentase $80 \%$ dari 17 siswa yang tergolong dalam kategori sangat baik. Berdasarkan hasil observasi mengenai kemampuan bercerita siswa dengan menggunakan model pembelajaran kerja kelompok kecil dapat disimpulkan bahwa kemampuan bercerita siswa baik dalam aspek kebahasaan maupun non kebahasaan menunjukkan capaian prosentase sebesar $84 \%$ dari keseluruhan indikator. Dimana angka tersebut termasuk dalam kategori kedua dengan rentan $80 \%$ - 100\%, sehingga termasuk dalam kategori "sangat baik". Hal ini sejalan dengan teori yang dikemukakan oleh Mulyasa (2007, hal. 92)

Dalam penelitian deskriptif yang peneliti lakukan menunjukan siswa sangat bersemangat dan antusias dalam mengikuti pembelajaran kemampuan bercerita menggunakan metode pembelajaran kerja kelompok kecil. Pelaksanaan pembelajaran keterampilan bercerita dengan menggunakan model pembelajaran kerja kelompok kecil, siswa terlihat aktif berlatih secara berkelompok, pembelajaran kerja kelompok kecil ini dapat memotivasi siswa untuk belajar lebih baik dalam menggunakan dan mengucapkan kalimat dengan bahasa Indonesia dan dapat meningkatkan keterampilan bercerita siswa.

\section{PENUTUP}

Keterlaksanaan pembelajaran kemampuan bercerita menggunakan model pembelajaran kerja kelompok kecil pada tema 6 energi dan perubahannya siswa kelas III di SD Negeri 02 Penjor dengan jumlah 17 siswa, terdapat 14 siswa memiliki kemampuan bercerita yang sangat baik, dan 3 siswa yang kemampuan berceritanya memenuhi dalam kategori baik. Hal tersebut terlihat dari hasil observasi pelaksanaan pembelajaran kemampuan bercerita tema 6 energi dan perubahannya menggunakan 
metode pembelajaran kelompok kecil memperoleh skor 501 dengan prosentase $84 \%$ yang dalam kategori "sangat baik".

Kemampuan bercerita siswa menggunakan model pembelajaran kerja kelompok kecil pada tema 6 energi dan perubahannya siswa kelas III di SD Negeri 02 kemampuan bercerita tema 6 energi dan perubahannya menggunakan metode pembelajaran kelompok kecil memperoleh skor 501 dengan prosentase $84 \%$ yang dalam kategori "sangat baik". dapat disimpulkan bahwa pembelajaran kemampuan bercerita dengan menggunakan model pembelajaran kerja kelompok kecil ini dapat memotivasi siswa untuk belajar lebih baik dalam menggunakan dan mengucapkan kalimat dengan bahasa Indonesia dan dapat meningkatkan keterampilan bercerita siswa. Dalam upaya peningkatan mutu pendidikan di sekolah dasar.

Sarannya kepada sekolah sebagai tolak ukur bagaimana upaya untuk meningkatkan kemampuan bercerita siswa, dan sekolah dapat menyediakan sarana dan prasarana yang memadai agar proses belajar mengajar menjadi lebih baik lagi. Kepada guru diharapkan menggunakan media kartu bergambar saat proses pembelajaran, agar pembelajaran menjadi lebih menyenangkan dan hasil yang diperoleh siswanya lebih memuaskan dalam pembelajaran. Bagi peneliti selanjutnya disarankan untuk melakukan penelitian lain guna mengetahui peningkatan pembelajaran pada aspek pembelajaran yang lain agar dapat memperoleh wawasan yang cukup sebagai bekal dalam dunia pendidikan.

\section{UCAPAN TERIMAKASIH}

Terimakasih kepada Ketua STKIP PGRI Tulungagung, Kepada Wakil Ketua Bidang Akademik, Kepada Ketua Program Studi Pendidikan Guru Sekolah Dasar, Kepada Bapak/lbu dosen pembimbing, Kepala SDN 02 Penjor beserta jajarannya, dan kepada Ibu Sulastri selaku pendukung moral maupun materil.

\section{DAFTAR PUSTAKA}

Afrizal. 2014. Metode Penelitian Kualitatif. Jakarta: Rajagrafindo.

Ahmadi, Abu. 1997. Strategi Belajar Mengajar. Pustaka Setia. Bandung.

Bachir, Bachtiar S. 2005. Pengembangan Kegiatan Bercerita di Taman Kanak-Kanak dan Teknik dan Prosedurnya. Jakarta: Depdiknas.

Moleong, J. Lexy. 2011. Metodologi Penelitian Kualitatif. Bandung: Remaja Rosdakarya.

Mulyasa, 2007. Menjadi Guru Profesional; Menciptakan Pembelajaran Kreatif dan Menyenangkan. Bandung: Rosdakarya. 